\title{
mRNA expression of somatostatin receptor subtypes SSTR-2, SSTR-3, and SSTR-5 and its significance in pancreatic cancer
}

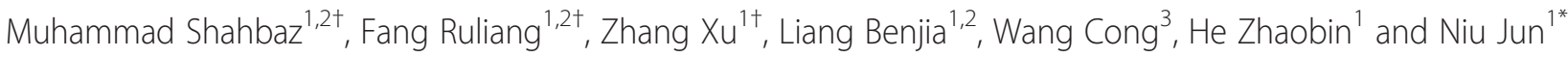

\begin{abstract}
Background: The aim of this study is to investigate the expressions of somatostatin receptor (SSTR), SSTR-2, SSTR-3, and SSTR-5, in pancreatic tissue and non-cancerous tissue and elucidate their clinical significance.

Methods: The expression of somatostatin receptor subtypes SSTR-2, SSTR-3, and SSTR-5 messenger RNA (mRNA) in 108 cases of cancer tissue and adjacent tissue in patients with pancreatic cancer was detected by reverse transcriptase polymerase chain reaction (RT-PCR). Expression of SSTR-2, SSTR-3, and SSTR-5 mRNA was evaluated after specimens were taken from selected patients who underwent surgical resection by Whipple's operation. We speculated the clinical significance of the expression of somatostatin receptor (SSTR) subtype genes SSTR-2, SSTR-3, and SSTR-5 in pancreatic tissue and non-cancerous tissue and further elucidated their clinical significance.

Results: The expression rates of SSTR-2 mRNA in cancer and adjacent tissue of 108 patients with pancreatic cancer were $81.5 \%$ (88/108) and 97.2\% (105/108), respectively; SSTR-3 mRNA expression rates were 69.4\% (75/108) and 55.6\% (60/108). SSTR-5 mRNA expression rates were 13.0\% (14/108) and 18.5\% (20/108).

Conclusion: We propose that SSTR-2 plays an important role in clinical implications for patients with pancreatic cancer undergoing somatostatin or its analog therapy.
\end{abstract}

Keywords: Pancreatic cancer, Somatostatin receptor, mRNA

\section{Background}

Somatostatin is a type of peptide hormone which has a wide range of biological functions. Recent studies have indicated that somatostatin and its analogs have obvious anti-proliferative effects on various solid tumors, such as gastroenteropancreatic neuroendocrine tumors and breast cancer, which are mediated through somatostatin receptors $[1,2]$, but some clinical research have indicated that the impact of somatostatin and its analog receptor expression levels on outcomes in patients with pancreatic neuroendocrine tumors (PNETS) has not been evaluated [3,4]. Thus, whether or not there is expression of somatostatin receptor (somatostatin receptor, SSTR) in tumor tissue is an important underlying factor affecting the efficacy of somatostatin therapy. In this study, we detected the

\footnotetext{
* Correspondence: sdusurg@gmail.com

${ }^{\dagger}$ Equal contributors

'Department of Hepatobiliary Surgery, Qilu Hospital, Shandong University, Wenhua west Road \#44, Jinan 250012, China

Full list of author information is available at the end of the article
}

expression of somatostatin receptor subtypes SSTR-2, SSTR-3, and SSTR-5 messenger RNA (mRNA) from 108 cases of cancer tissue and adjacent tissue in patients with pancreatic cancer using RT-PCR method. Thereafter, we explored the clinical implications of somatostatin therapy for patients with pancreatic cancer. Our study is aimed at exploring the cause from different therapeutic effects of somatostatin and its analogs on human pancreatic cancer and their relationship between changes of SSTR-2 gene expression and expression of SSTR-2, SSTR-3, and SSTR-5 genes [5].

\section{Methods \\ Patient population and data collection \\ Our study was a retrospective analysis of patients who had been diagnosed pathologically as having pancreatic ductal adenocarcinoma by the Department of Pathology in Qilu hospital, between January 2010 and June 2013. The demographic, clinical, laboratory, and radiological}


data for all patients admitted or transferred to our hospital with a diagnosis of pancreatic ductal adenocarcinoma were reviewed retrospectively for this study. Included in this study, patients with pancreatic cancer must have received surgical resection as the initial treatment modality without major perioperative complications, have adequate archived tissue kept, and have complete clinicopathologic data obtained. This resulted in a collection of tissue from 108 patients, 72 males and 36 females with a median age of 55.7 years and an age range of 33 to 71 years. Among those, 85 had cases of carcinoma of the head of the pancreas and 23 cases of carcinoma of the body and tail of the pancreas. For UICC TNM clinical stages: stages I to II had 33 cases, and stages III to IV had 75 cases. We also collected the non-cancerous pancreatic tissue from 10 patients (all by excision of the normal pancreas were taken from surgical specimens) in order to compare the mRNA expression rate with the cancerous pancreatic tissues and adjacent normal tissue. The pathologic tumornode-metastasis (TNM) classification was based on the criteria of the International Union Against Cancer (2009). The study protocol was approved by the Ethics Committee of Qilu Hospital affiliated to Shandong University. Informed consent was obtained from each patient prior to

Table 1 The basic characteristics of patients in this study

\begin{tabular}{|c|c|c|c|c|c|c|c|c|c|c|}
\hline \multirow{2}{*}{$\begin{array}{l}\text { Clinical pathological } \\
\text { factors }\end{array}$} & \multirow{2}{*}{$\begin{array}{l}n \\
108\end{array}$} & \multicolumn{2}{|c|}{ SSTR-2 mRNA } & \multirow[t]{2}{*}{$P$ value } & \multicolumn{2}{|c|}{ SSTR-3 mRNA } & \multirow[t]{2}{*}{$P$ value } & \multicolumn{2}{|c|}{ SSTR-5 mRNA } & \multirow[t]{2}{*}{$P$ value } \\
\hline & & $\begin{array}{l}\text { Positive } \\
(n=88)\end{array}$ & $\begin{array}{l}\text { Negative } \\
(n=20)\end{array}$ & & $\begin{array}{l}\text { Positive } \\
(n=75)\end{array}$ & $\begin{array}{l}\text { Negative } \\
(n=33)\end{array}$ & & $\begin{array}{l}\text { Positive } \\
(n=14)\end{array}$ & $\begin{array}{l}\text { Negative } \\
(n=94)\end{array}$ & \\
\hline Gender & & & & $P<0.05^{* *}$ & & & $P<0.05^{* *}$ & & & $P>0.05$ \\
\hline Male & 56 & 40 & 16 & & 33 & 23 & & 8 & 48 & \\
\hline Female & 52 & 48 & 4 & & 42 & 10 & & 6 & 46 & \\
\hline Age (years) & & & & $P>0.05$ & & & $P>0.05$ & & & $P>0.05$ \\
\hline$<60$ & $\begin{array}{l}406836 \\
322246\end{array}$ & $\begin{array}{l}356836 \\
322246\end{array}$ & 5 & & $\begin{array}{l}276836 \\
322246\end{array}$ & 13 & & 5 & 35 & \\
\hline$\geq 60$ & 68 & 53 & 15 & & 48 & 20 & & 9 & 59 & \\
\hline T stage & & & & $P>0.05$ & & & $P>0.05$ & & & $P>0.05$ \\
\hline $\mathrm{T} 1$ & 1 & 0 & 1 & & 0 & 1 & & 0 & 1 & \\
\hline $\mathrm{T} 2$ & 13 & 11 & 2 & & 9 & 5 & & 2 & 11 & \\
\hline T3 & 45 & 36 & 9 & & 35 & 10 & & 5 & 40 & \\
\hline $\mathrm{T} 4$ & 49 & 41 & 8 & & 32 & 17 & & 7 & 42 & \\
\hline N stage & & & & $P>0.05$ & & & $P>0.05$ & & & $P>0.05$ \\
\hline No & 63 & 53 & 10 & & 42 & 21 & & 7 & 56 & \\
\hline N1 & 34 & 28 & 6 & & 25 & 9 & & 5 & 29 & \\
\hline N2 & 11 & 7 & 4 & & 8 & 3 & & 2 & 9 & \\
\hline M stage & & & & $P>0.05$ & & & $P>0.05$ & & & $P>0.05$ \\
\hline MO & 84 & 67 & 17 & & 58 & 26 & & 9 & 75 & \\
\hline M1 & 24 & 21 & 3 & & 17 & 7 & & 5 & 19 & \\
\hline TNM stage & & & & $P>0.05$ & & & $P>0.05$ & & & $P>0.05$ \\
\hline | to || & 40 & 31 & 9 & & 27 & 13 & & 6 & 34 & \\
\hline III to IV & 68 & 57 & 11 & & 48 & 20 & & 8 & 60 & \\
\hline Differentiation & & & & $P>0.05$ & & & $P>0.05$ & & & $P>0.05$ \\
\hline Well & 40 & 33 & 7 & & 30 & 10 & & 4 & 36 & \\
\hline Moderate & 45 & 35 & 10 & & 29 & 16 & & 5 & 40 & \\
\hline Poor/undifferentiated & 23 & 20 & 3 & & 16 & 7 & & 5 & 18 & \\
\hline $\begin{array}{l}\text { Survival (60-month } \\
\text { follow-up) }\end{array}$ & & & & $P<0.05^{*}$ & & & $P>0.05$ & & & $P>0.05$ \\
\hline Death & 90 & 70 & 20 & & 63 & 27 & & 11 & 79 & \\
\hline Censored & 18 & 18 & 0 & & 12 & 6 & & 3 & 15 & \\
\hline
\end{tabular}

The expression of SSTR-2 was significantly relevant with the survival rate. The survival rate of patients with positive expression was higher than those with negative expression $\left(P<0.05^{*}\right)$. The expressions of SSTR-2 mRNA and SSTR-3 mRNA were relevant with gender. Female positive rate was significantly higher than male $\left(P<0.05^{* *}\right)$. These three kinds of mRNA expression had no obvious relationships with age, TNM stage, and differentiation $(P>0.05)$. 
study enrollment at the time of hospital admission, and the detailed case characteristics are summarized in Table 1.

\section{Reagents}

Total RNA extraction reagents were bought from Promega (Madison, WI, USA). Specific primers, RT-PCR reagents and restriction enzymes, were provided by TaKaRa (Bio Company, Kyoto, Japan).

\section{Specimen collection}

Non-necrotic cancer tissue and adjacent normal tissue ( $3 \mathrm{~cm}$ from cancer tissue) were taken from surgical specimens (non-cancerous pancreatic tissues were taken from the normal tissue). All were frozen in liquid nitrogen immediately after removal and placed in $-80^{\circ} \mathrm{C}$.

\section{RT-PCR}

Complementary DNA (cDNA) was synthesized by reverse transcription of $20 \mu \mathrm{l}$ total RNA in a reaction system. Following reaction system was used: $\mathrm{MgCl}_{2} 5 \mathrm{mmol} / \mathrm{L}$, dNTPs $5 \mathrm{mmol} / \mathrm{L}$, RNAsin 20U, AMV reverse transcriptase XL2.5U, oligo d (T) adaptor primers $2.5 \mu \mathrm{mol} / \mathrm{L}$. The reaction was carried out at $65^{\circ} \mathrm{C}$ for $10 \mathrm{~min}$; after cooling at $4^{\circ} \mathrm{C}$ for $5 \mathrm{~min}$, AMV reverse transcriptase $\mathrm{Xl}$ was added and then incubated at $42^{\circ} \mathrm{C}$ for $60 \mathrm{~min}, 99^{\circ} \mathrm{C}$ heating for 5 min to inactivate the reverse transcriptase. PCR was performed using the following schedule: 30 cycles of denaturation at $94^{\circ} \mathrm{C}$ for $30 \mathrm{~s}$; annealing of SSTR-2 and SSTR-5 at $57^{\circ} \mathrm{C}$ for $30 \mathrm{~s}$ and $S S T R-3$ at $63^{\circ} \mathrm{C}$ for $60 \mathrm{~s}$; positive control at $60^{\circ} \mathrm{C}$ for $30 \mathrm{~s}$; extension at $72^{\circ} \mathrm{C}$ for $1 \mathrm{~min}$; frozen at $4^{\circ} \mathrm{C}$ for $5 \mathrm{~min}$. Special primer pairs were listed as supplementary Table 2 .

\begin{tabular}{|c|c|c|}
\hline Primers & Sequences of primers & $\begin{array}{l}\text { Size of PCR } \\
\text { products (bp) }\end{array}$ \\
\hline \multicolumn{3}{|l|}{ SSTR-2 } \\
\hline Sense & 5'-CATCATTGGGTTGTGTGCA-3' (162 to 181) & 256 \\
\hline Antisense & 5'-GCTCGATGCTCATGACTGTC-3' (399 to 418) & \\
\hline \multicolumn{3}{|l|}{ SSTR-3 } \\
\hline Sense & 5'-TGGCATTGGGTTGTTCATG-3' (263 to 282) & 435 \\
\hline Antisense & 5'-CTTCACCAGGGTTGTGTGTAG-3' (675 to 696) & \\
\hline \multicolumn{3}{|l|}{ SSTR-5 } \\
\hline Sense & 5'-GTTCATTGGGTTGTGTGCG-3' (169 to 187) & 101 \\
\hline Antisense & 5'-CAACATTGGGTTGTGTGCC-3' (262 to 381) & \\
\hline \multicolumn{3}{|c|}{ Positive control } \\
\hline$F-1$ & 5'-CATCATTGGGTTGTGTGCA-3' & 462 \\
\hline $\mathrm{R}-1$ & 5'-CATCATTGGGTTGTGTGCA-3' & \\
\hline
\end{tabular}

\section{Statistical method}

All statistical data was evaluated by $\chi^{2}$ test. The $P<0.05$ was considered statistically significant while three samples were compared. While comparing two samples, we used partitions of $\chi^{2}$ method to significant level $\alpha^{\prime} \cdot \alpha^{\prime}=\alpha /((\mathrm{k}-1) \times k / 2+1)(k$, numbers of combination of any two). We could calculate the outcome of $\alpha^{\prime}$ is 0.0125 . Thus, $P<0.0125$ was considered statistically significant. Survival analyses were conducted by the life table method and the log-rank test. $P$ values $<0.05$ were considered to be statistically significant. Survival curves were generated through the life table method.

\section{Results}

In 108 cases of pancreatic cancer patients, the expression rate of SSTR-2 receptor mRNA in adjacent cancer tissues was $97.2 \%(105 / 108)$ and in cancer tissue was $81.5 \%$ (88/108) (Table 3). The rate of positive SSTR-2 mRNA expression among carcinous tissue, adjacent tissue of cancer, and non-carcinous pancreatic tissues were significantly different via analysis $(P<0.01)$. When compared between any two groups, the difference between carcinous tissue and adjacent tissue was also significant. Positive expression in carcinous tissue was also higher than adjacent tissue $(P<0.0125)$ (Table 3$)$. Analysis from other groups did not show obvious differences $(P>0.0125)$. The expression rate of SSTR-3 receptor mRNA in adjacent cancer tissue was $55.6 \%(60 / 108)$. In cancer tissue, it was $69.4 \%$ (75/108) (Table 3). The expression rate of SSTR-5 receptor mRNA in adjacent cancer tissues was $18.5 \%$ (20/108).

Table 3 SSTR-2, SSTR-3, and SSTR-5 mRNA expression in different tissues

\begin{tabular}{|c|c|c|c|c|}
\hline Tissue & Positive (n) & Negative ( $n$ ) & Total & $\begin{array}{l}\text { Positive } \\
\text { rate }\end{array}$ \\
\hline $\begin{array}{l}\text { SSTR-2 mRNA expression } \\
\text { Carcinous tissues }\end{array}$ & 88 & 20 & 108 & $81.5 \%$ \\
\hline Adjacent cancerous tissues & 105 & 3 & 108 & $97.2 \%$ \\
\hline $\begin{array}{l}\text { Non-carcinous pancreatic } \\
\text { tissues }\end{array}$ & 10 & 0 & 10 & $100 \%$ \\
\hline Total & 203 & 23 & 226 & $89.8 \%$ \\
\hline $\begin{array}{l}\text { SSTR-3 mRNA expression } \\
\text { Carcinous tissues }\end{array}$ & 75 & 33 & 108 & $69.4 \%$ \\
\hline Adjacent cancerous tissues & 60 & 48 & 108 & $55.6 \%$ \\
\hline $\begin{array}{l}\text { Non-carcinous pancreatic } \\
\text { tissues }\end{array}$ & 7 & 3 & 10 & $70 \%$ \\
\hline Total & 142 & 84 & 226 & $62.8 \%$ \\
\hline $\begin{array}{l}\text { SSTR-5 mRNA xpression } \\
\text { Carcinous tissues }\end{array}$ & 14 & 94 & 108 & $13.0 \%$ \\
\hline Adjacent cancerous tissues & 20 & 88 & 108 & $18.5 \%$ \\
\hline $\begin{array}{l}\text { Non-carcinous pancreatic } \\
\text { tissues }\end{array}$ & 1 & 9 & 10 & $10 \%$ \\
\hline Total & 35 & 191 & 226 & $15.5 \%$ \\
\hline
\end{tabular}


In cancer tissues, it was $13 \%(14 / 108)$ (Table 4). SSTR-2, SSTR-3, and SSTR-5 mRNA expression rate of ten cases of non-cancerous pancreatic tissue were $100.0 \%(10 / 10)$, $70.0 \%(7 / 10)$, and $10.0 \%(1 / 10)$ (Table 2$)$.

No significant differences were showed among three groups or the combination of any two groups via $\chi^{2}$ tests. Thus, we could draw a conclusion that the SSTR-3 mRNA expression among carcinous tissue, adjacent tissue of cancer, and non-carcinous tissue were similar (Table 4).

We concluded that the expression of SSTR-2 was significantly associated with survival rates (Table 1). The survival rate of patients with a positive expression was higher than those with a negative expression $\left(P<0.05^{*}\right)$. The expression of SSTR-2 mRNA and SSTR-3 mRNA were relevant with gender. The female positive rate was significantly higher than males $\left(P<0.05^{* *}\right)$. These three kinds of mRNA's expressions had no obvious relationships with age, TNM stage, and cancer differentiation $(P>0.05)$.

Survival curves are shown in Figure 1a-c. Patients with positive SSTR-2 mRNA expression in carcinous tissue had a significantly better overall survival rate than those with negative expression $\left(P<0.05\right.$, the log-rank test, $\mathrm{x}^{2}=$ 4.40). The difference of a patients' survival rate between positive and negative SSTR-3 expression in carcinous tissue had no statistical significance $(P>0.05$, the log-rank test, $X 2=0.003)$, and the difference of a patients' survival rate between positive and negative SSTR-5 expression in carcinous tissue also had no statistical significance $(P>$ 0.05 , the log-rank test, $\chi^{2}=0.391$ ).

Table 4 The $x^{2}$ test outcomes of SSTR-2, SSTR-3, and SSTR-5 mRNA expression

\begin{tabular}{lll}
\hline Samples & $\mathbf{X}^{\mathbf{2}}$ & $\boldsymbol{P}$ \\
\hline SSTR-2 mRNA expression Three groups & 15.82 & $P<0.01$ \\
$\begin{array}{l}\text { Carcinous tissues and adjacent cancerous } \\
\text { tissues cancer }\end{array}$ & 14.06 & $P<0.0125$ \\
Carcinous tissues and non-carcinous tissues & 2.23 & $P>0.0125$ \\
$\begin{array}{l}\text { Adjacent cancerous tissues and non-carcinous } \\
\text { tissues }\end{array}$ & 0.29 & $P>0.0125$ \\
$\begin{array}{l}\text { SSTR-3 mRNA expression Three groups } \\
\text { Carcinous tissues and adjacent cancerous }\end{array}$ & 4.69 & $P>0.05$ \\
$\begin{array}{l}\text { tissues } \\
\text { Carcinous tissues and non-carcinous tissues }\end{array}$ & 0.44 & $P>0.0125$ \\
$\begin{array}{l}\text { Adjacent cancerous tissues and non-carcinous } \\
\text { tissues }\end{array}$ & 0.78 & $P>0.0125$ \\
$\begin{array}{l}\text { SSTR-5 } m R N A \text { expression Three groups } \\
\text { Carcinous tissues and adjacent cancerous }\end{array}$ & 1.51 & $P>0.05$ \\
$\begin{array}{l}\text { tissues } \\
\text { Carcinous tissues and non-carcinous tissues }\end{array}$ & 0.07 & $P>0.0125$ \\
$\begin{array}{l}\text { adjacent cancerous tissues and non-carcinous } \\
\text { tissues }\end{array}$ & 0.45 & $P>0.0125$ \\
\hline
\end{tabular}

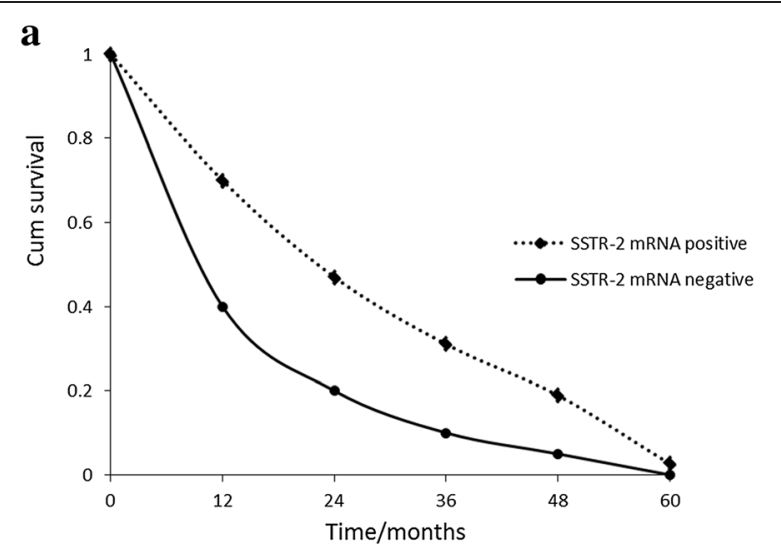

b

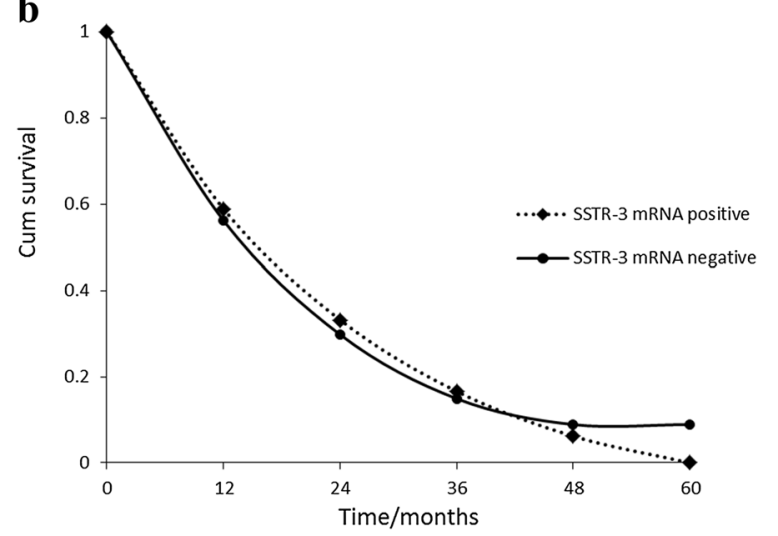

c

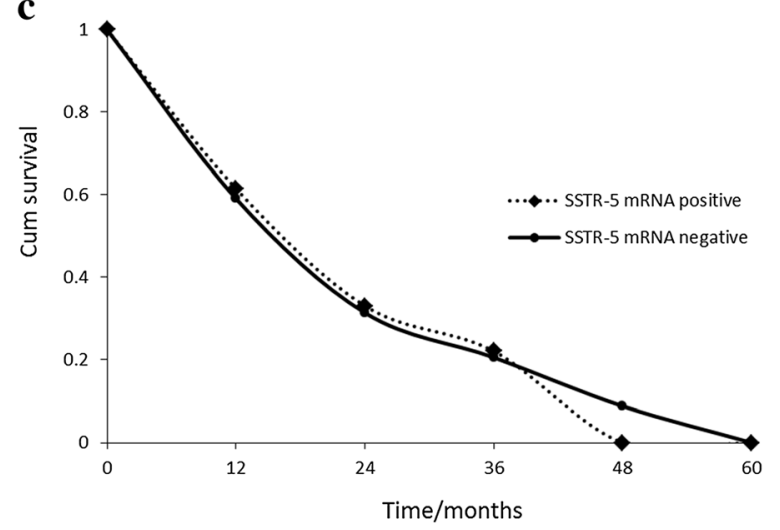

Figure 1 Overall survival according to SSTR-2,SSTR-3,SSTR-5

mRNA expression in pancreatic cancer patients. (a) Overall

survival according to SSTR-2 mRNA expression in pancreatic cancer patients. (b) Overall survival according to SSTR-3 mRNA expression in pancreatic cancer patients. (c) Overall survival according to SSTR-5 mRNA expression in pancreatic cancer patients.

\section{Discussion}

Somatostatin can inhibit growth of pancreatic cancer cells even in CPT-insensitive human pancreatic carcinoid BON cells [6]. The inhibition mechanism involves the combined interaction of somatostatin and its analogs with SSTR-2 in tumor tissues, mainly through binding to tumor tissue receptors [7], which directly inhibits tumor cell proliferation. 
This occurs through the process of either directly inhibiting division and proliferation of tumor cells or inhibiting the activity of various growth factors, such as vascular endothelial growth factor (VEGF), insulin-like growth factor (IGF) and marked stimulation of the reticuloendothelial system [8,9]. Moreover, it counteracts tumorigenesis and tissue proliferation. In addition, it was found that somatostatin and its analogs could arrest the pancreatic cancer cell cycle at $\mathrm{S}$ phase and thus induce apoptosis [10]. In cloned somatostatin receptor subtypes, synthetic long-acting somatostatin analogs 6 or 8 , such as octreotide and vapreotide have high affinity to SSTR-2 and SSTR-5 receptor subtypes, low affinity to SSTR-3, and no affinity to other types of receptor subtypes [11]. Therefore, before implementing therapy by long-acting somatostatin analogs such as octreotide in pancreatic cancer patients, to make sure that tumor tissue have high affinity somatostatin receptors, it is important to improve efficacy and reduce unnecessary costs. There is genre and organ specificity in the expression of somatostatin receptors; for example, the normal pancreas mainly expresses SSTR-2 subtype receptors, while only SSTR-3 genes are expressed in rat pancreatic tissue; in the outer periphery of the body organization, only SSTR-5 subtype receptors are found in the hypothalamus and pituitary tissue [12]. Therefore, in relation to drug receptor binding affinity and organspecific aspects, we studied SSTR-2, SSTR-3, and SSTR-5 expression in the pancreatic cancer.

There are few reports about research on somatostatin receptor gene expression in pancreatic tumor tissue. Somatostatin receptor expression in pancreatic tissue is detected by using isotopically labeled somatostatin [13]. However, because natural or synthetic somatostatin can bind to various somatostatin receptors, we cannot determine which kind of somatostatin subtype receptor binds to isotopically labeled somatostatin. RT-PCR assay has good specificity and high sensitivity for detection of SSTR-2 gene expression in tumor specimens.

From the results of this study, there were 88 cases with positive expression of SSTR-2 mRNA out of 108 pancreatic cancer cases; thus, the rate was $81.5 \%$. This shows that the majority of pancreatic tumor tissues have SSTR-2 receptor subtype expression. Because the current study shows that the ability of somatostatin to inhibit tumor cell growth is mediated by SSTR-2 [14,15], it is very important for patients suffering from pancreatic cancer to receive somatostatin treatment. In experimental pancreatic tumor, the growth of both functioning pancreatic tumors and nonfunctioning tumors with SSTR-2 gene expression is inhibited by somatostatin, while there is no inhibitory effect on non-SSTR-2 gene expression cells. Carcinoid patients had a similar situation [16]. Researchers believe that the expression of SSTR-2 in tumor tissue is the premise for patients to accept somatostatin therapy. In addition, SSTR-3 mRNA expression was higher in pancreatic tumor tissue than the adjacent tissue of cancer, and the rate of positive expression decreases with increasing degree of differentiation trend. Significance of pancreatic tissue SSTR-3 mRNA expression is still unclear. Compared with SSTR-2, SSTR-3 has low affinity when compared to six or eight peptide long-acting somatostatin analogs, so further study is needed to determine its role in the treatment of tumors.

There is less difference in the rate of SSTR-5 mRNA expression in pancreatic tumor tissue and tumor adjacent tissue, both were low, which is consistent with previous findings [17]. Synthetic six or eight long-acting somatostatin analogs like octreotide and vapreotide have high affinity to the SSTR-5 receptor subtype [10]; its specific mechanism in pancreatic cancer remains to be further explored.

\section{Conclusions}

In summary, our findings indicated that the majority of pancreatic cancers have more than one somatostatin receptor subtype gene. According to recent studies, we obtained that somatostatin and its analogs have obvious anti-proliferative effects on various solid tumors which are mediated through somatostatin receptors. We propose that the SSTR-2 could play an important role in clinical implications for patients with pancreatic cancer undergoing somatostatin or its analog therapy.

\section{Abbreviations \\ SSTR: somatostatin receptor; RT-PCR: reverse transcriptase polymerase chain reaction; PNETs: pancreatic neuroendocrine tumors; VEGF: vascular endothelial growth factor; IGF: insulin-like growth factor.}

\section{Competing interests}

The authors declare that they have no competing interests.

\section{Authors' contributions}

$M S, R L, Z X, B J$, and $C W$ were responsible for designing and performing the study, literature research, and manuscript writing; CW, MS, BJ, and ZX were responsible for data acquisition and graphical interpretation of the data. MS and $C W$ were responsible for the data analysis. MS, BJ, ZX, CW, NJ, and RL were responsible for critical review of the manuscript. All authors approved the final version of the manuscript.

\section{Acknowledgements}

This study was supported by the research Grants from the National Natural Sciences Foundation of China (No. 81272653), the Natural Sciences Foundation of Shandong Province (No. ZR2011HM003), and Shandong Province Outstanding Young Scientists Funds (No. BS2011YY020).

\section{Author details}

'Department of Hepatobiliary Surgery, Qilu Hospital, Shandong University, Wenhua west Road \#44, Jinan 250012, China. ${ }^{2}$ Key Laboratory of Cardiovascular Remodeling and Function Research, Chinese Ministry of Education and Public Health, Jinan 250012, Shandong, People's Republic of China. ${ }^{3}$ Department of Radiation Oncology, Qilu Hospital, Shandong University, Jinan 250012, China.

Received: 29 June 2014 Accepted: 17 January 2015

Published online: 13 February 2015 


\section{References}

1. Baldelli R, Barnabei A, Rizza L, Isidori AM, Rota F, Di Giacinto P, et al. Somatostatin analogs therapy in gastroenteropancreatic neuroendocrine tumors: current aspects and new perspectives. Front Endocrinol (Lausanne). 2014;5:7.

2. Margheri M, Pacini N, Tani A, Nosi D, Squecco R, Dama A, et al. Combined effects of melatonin and all-trans retinoic acid and somatostatin on breast cancer cell proliferation and death: molecular basis for the anticancer effect of these molecules. Eur J Pharmacol. 2012;681:34-43.

3. Okuwaki K, Kida M, Mikami T, Yamauchi H, Imaizumi H, Miyazawa S, et al. Clinicopathologic characteristics of pancreatic neuroendocrine tumors and relation of somatostatin receptor type $2 \mathrm{~A}$ to outcomes. Cancer. 2013;119:4094-102.

4. Yenıy L, Gürcü B, Ünalp Ö, Yilmaz F, Nart D, Sözbılen M, et al. Prognostic value of somatostatin receptor-2 positivitiy in gastroenteropancreatic neuroendocrine tumors in reference to known prognostic factors. Turk J Gastroenterol. 2012:23:736-40.

5. Mizutani G, Nakanishi Y, Watanabe N, Honma T, Obana Y, Seki T, et al. Expression of somatostatin receptor (SSTR) subtypes (SSTR-1, 2A, 3, 4 and 5) in neuroendocrine tumors using real-time RT-PCR method and immunohistochemistry. Acta Histochem Cytochem. 2012;45:167-76.

6. Sun LC, Coy DH. Somatostatin receptor-targeted anti-cancer therapy. Curr Drug Deliv. 2011;8:2-10.

7. Starkey JR, Pascucci EM, Drobizhev MA, Elliott A, Rebane AK. Vascular targeting to the SST2 receptor improves the therapeutic response to near-IR two-photon activated PDT for deep-tissue cancer treatment. Biochim Biophys Acta. 2013;1830:4594-603.

8. Dal Monte M, Latina V, Cupisti E, Bagnoli P. Protective role of somatostatin receptor 2 against retinal degeneration in response to hypoxia. Naunyn Schmiedebergs Arch Pharmacol. 2012;385:481-94.

9. Nott DM, Baxter JY, Grime JS, Day DW, Cooke TG, Jenkins SA. Effects of a somatostatin analogue (SMS201-995) on the growth and development of pancreatic tumor derived by intraportal injection of Walker cells in the rat. Br J Surg. 1989;76:1149-51.

10. Kuriyama I, Miyazaki A, Tsuda Y, Yokoi T, Okada Y, Takeuchi T, et al. Inhibitory effect of somatostatin peptide analogues on DNA polymerase activity and human cancer cell proliferation. Anticancer Res. 2010;30:4841-9.

11. Zou Y, Xiao X, Li Y, Zhou T. Somatostatin analogues inhibit cancer cell proliferation in an SSTR2-dependent manner via both cytostatic and cytotoxic pathways. Oncol Rep. 2009;21:379-86.

12. Patel YC, Greenwood MT, Panetta R, Demchyshyn L, Niznik H, Srikant CB. The somatostatin receptor family. Life Sci. 1995;57:1249-65.

13. Fisher WE, Muscarella P, O'Dorisio TM. Expression of the somatostatin receptor subtype-2 gene predicts response of human pancreatic cancer to octreotide. Surgery. 1996;120:234-40. discussion 240-1.

14. Stumm R. Somatostatin receptor SST2 reduces Akt activity and aggravates hypoxic/ischemic death in cerebral cortical neurons. Neuropharmacology. 2014;77:249-56

15. Shi X, Li X, Chen L, Wang C. Analysis of somatostatin receptors and somatostatin promoter methylation in human gastric cancer. Oncol Lett. 2013;6:1794-8

16. Nakayama Y, Wada R, Yajima N, Hakamada K, Yagihashi S. Profiling of somatostatin receptor subtype expression by quantitative PCR and correlation with clinicopathological features in pancreatic endocrine tumors. Pancreas. 2010:39:1147-54

17. Li M, Li W, Kim HJ, Yao Q, Chen C, Fisher WE. Characterization of somatostatin receptor expression in human pancreatic cancer using real-time RT-PCR. J Surg Res. 2004;119:130-7.

\section{Submit your next manuscript to BioMed Central and take full advantage of:}

- Convenient online submission

- Thorough peer review

- No space constraints or color figure charges

- Immediate publication on acceptance

- Inclusion in PubMed, CAS, Scopus and Google Scholar

- Research which is freely available for redistribution 